\title{
The gastric secretory response to a continuous insulin infusion in the dog
}

\author{
R. R. DOZOIS, D. C. CARTER, AND J. R. KIRKPATRICK \\ From the Department of Clinical Surgery, University of Edinburgh, Scotland
}

SUMmARY The gastric acid response to graded doses of insulin given by continuous infusion was studied in four dogs, each surgically provided with a gastric fistula. All doses of insulin resulted in a prolonged plateau of hypoglycaemia and the degree of hypoglycaemia correlated significantly $(\mathrm{P}<0.05)$ with the insulin dose, up to $0 \cdot 15 \mathrm{u} / \mathrm{kg} \mathrm{hr}$. Similarly, graded doses of insulin (up to $0 \cdot 15$ $\mathrm{u} / \mathrm{kg} \mathrm{hr}$ ) produced graded acid responses and both the peak acid output and the total acid output correlated significantly with blood glucose changes. No initial inhibitory phase of acid secretion followed the start of the infusion, but a dose-related delay in the onset of the acid response was observed. Our results indicate that insulin provides a quantitative glycopenic stimulus producing a quantitative vagal acid response.

Insulin hypoglycaemia provides a glycopenic stimulus producing a vagal gastric secretory response (Jögi, Ström, and Uvnäs, 1949). Earlier investigators (Hollander, Jemerin, and Weinstein, 1942; Davis, Brooks, and Robert, 1965) believed that the gastric acid response to insulin hypoglycaemia represented an 'all-or-none' phenomenon which was (1) initiated when the blood glucose fell to a given threshold value and (2) not related to the degree of hypoglycaemia below such a threshold. The recent finding, however, of a quantitative relationship between insulin dose, hypoglycaemia, and acid secretion (Baron, 1970; Spencer and Grossman, 1971) does not support the 'all-or-none' hypothesis.

A single rapid intravenous injection of insulin, such as used by the previously mentioned workers, produces a nadir of hypoglycaemia with gradual restoration of normoglycaemia. In human subjects (Carter, Dozois, and Kirkpatrick, 1972) an infusion of insulin provides a steady level of hypoglycaemia which, if reproducible in the dog, should facilitate correlation studies between blood glucose changes and gastric acid changes.

The present investigation was undertaken to study the effect of a continuous infusion of insulin on the blood glucose response in the dog and to establish the relationship between insulin dose, degree of hypoglycaemia, and acid response.

Received for publication 29 March 1973.

\section{Methods}

Four mongrel male dogs, 10 to $14 \mathrm{~kg}$ in weight, were each surgically provided with a chronic gastric fistula (Thomas, 1941). Following a three-week recovery period, the gastric secretory studies were started. The dogs were fasted for 20 hours before each test and stood on a Pavlov stand during the test.

After collection of two 15-minute samples of basal gastric secretion the insulin infusion was commenced. Soluble insulin (Insulin BP, Burroughs Wellcome), in doses of $0.025,0.05,0 \cdot 15$, and 0.30 units per $\mathrm{kg}$ of body weight per hour, was diluted in $154 \mathrm{mM} \mathrm{NaCl}$ and infused intravenously for three hours, using a constant slow injection pump (C. F. Palmer, London). Gastric juice was collected continuously for three hours and divided into 15-minute samples. The volume $(\mathrm{ml} / 15 \mathrm{~min})$ and acid concentration (m-equiv/l) were measured and the acid output (m-equiv/15 min) was calculated. All titrations were made to $\mathrm{pH} 7.0$ with $0.01 \mathrm{~N} \mathrm{NaOH}$, using an EIL titrimeter (Electronic Instruments Limited, Richmond, Surrey, England). Samples of venous blood were also obtained just before and every 30 minutes for two and a half hours after the start of the infusion and blood glucose levels determined by a glucose oxidase method using an AutoAnalyzer.

Three tests were carried out on each dog at each dose in random order. No animal was tested more than once every 48 hours. 


\section{Terminology}

The following variables of blood glucose were examined: (1) the plateau blood glucose (PBG), calculated as the mean of blood glucose values at $60,90,120$, and 150 minutes after the start of the infusion and expressed in $\mathrm{mg} / 100 \mathrm{ml}$; (2) the lowest blood glucose (LBG), being the lowest blood glucose value observed during the insulin infusion, expressed in $\mathrm{mg} / 100 \mathrm{ml}$; and (3) the $\Delta$ blood glucose ( $\Delta \mathrm{BG})$, being the difference between the initial fasting blood glucose and the plateau blood glucose, expressed as a percentage of the fasting blood glucose.

With regard to acid secretion, two variables were examined:(1) the peak acid output (PAO), calculated as the sum of the two highest consecutive 15-minute collections during the infusion, multiplied by 2 and expressed as m-equiv/hr (Baron, 1963); (2) the total acid output (TAO), calculated as the sum of all 12 15-minute samples during the insulin infusion, expressed as $\mathrm{m}$-equiv $/ 3 \mathrm{hr}$.

\section{Results}

\section{BLOOD GLUCOSE RESPONSE}

The pattern of blood glucose response to the insulin infusion was essentially the same for each dose in each dog (fig 1). By one hour, a level of hypoglycaemia was reached which remained fairly constant during the second and third hour of the infusion. There was a tendency for the lowest blood glucose value to be reached later during the infusion with

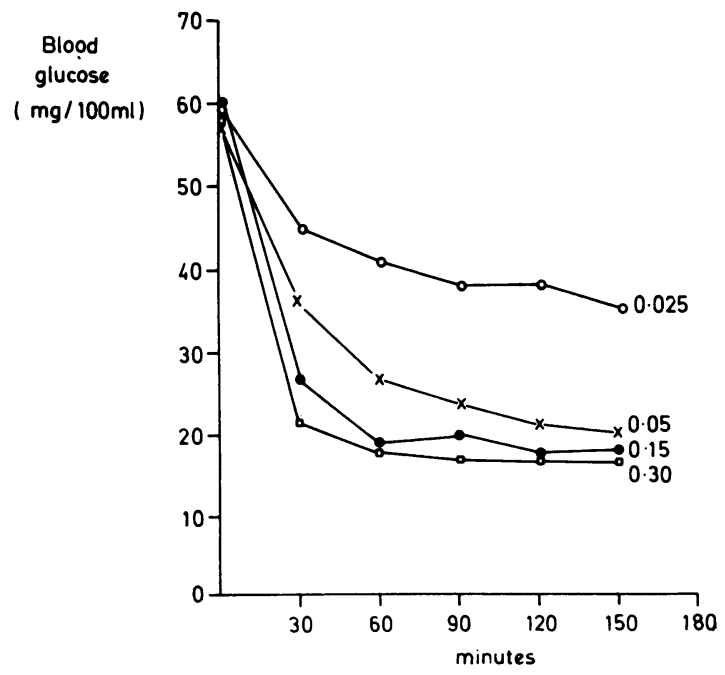

Fig 1 Pattern of blood glucose response to continuous infusion of insulin. Each point represents the overall mean of 12 observations in four dogs.

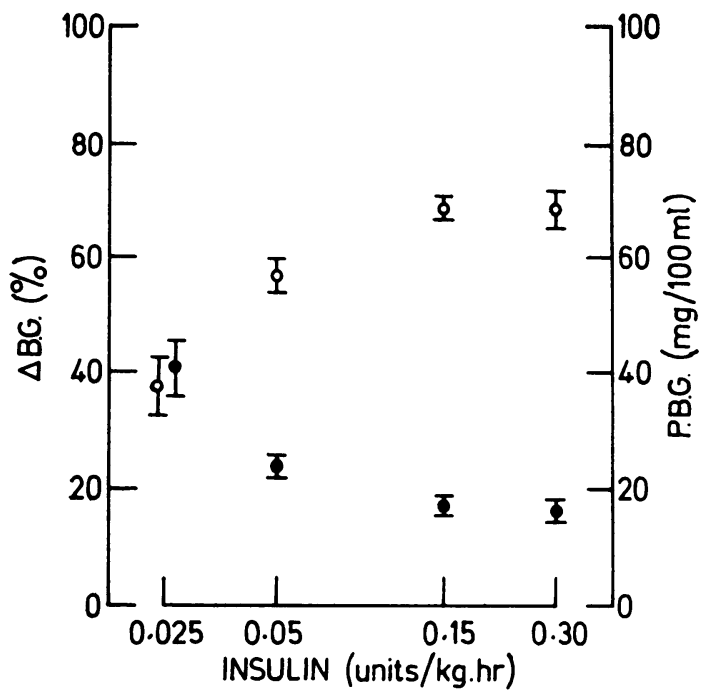

Fig 2 Blood glucose changes related to insulin dose. The $\triangle$ blood glucose $(\bigcirc)$ significantly $(p<0.02$ or less, Student's $t$ test for unpaired data) increased and the plateau blood glucose $(\bullet)$ significantly $(p<0.05$ or less, Student's $t$ test for unpaired data) decreased with increasing doses of insulin, up to $0.15 \mathrm{u} / \mathrm{kg} \mathrm{hr}$. Each point represents the mean of 12 observations in four dogs $( \pm S E)$.

the lowest two doses of insulin $(0.025$ and 0.05 $\mathrm{u} / \mathrm{kg} \mathrm{hr}$ ), but values obtained at $60,90,120$, and 150 minutes were not statistically different. The PBG and the LBG did not differ significantly. The PBG decreased and the $\Delta \mathrm{BG}$ increased significantly with increasing doses of insulin up to $0 \cdot 15 \mathrm{u} / \mathrm{kg} \mathrm{hr}$ (fig 2).

Blood glucose changes produced by the highest two doses of insulin $(0 \cdot 15$ and $0 \cdot 30 \mathrm{u} / \mathrm{kg} \mathrm{hr})$ were nearly identical, and accordingly the insulin doses (excluding $0.30 \mathrm{u} / \mathrm{kg} \mathrm{hr}$ ) correlated significantly with the PBG and the $\triangle B G$ (table I). These results indicate that increasing doses of insulin up to $0.15 \mathrm{u} / \mathrm{kg} \mathrm{hr}$

\begin{tabular}{lll}
\hline Dog & \multicolumn{1}{l}{$r^{1}$} & $p$ \\
\hline Plateau Blood Glucose & & \\
A & -0.70 & $<0.05$ \\
B & -0.85 & $<0.01$ \\
C & -0.71 & $<0.05$ \\
D & -0.86 & $<0.01$ \\
$\Delta$ Blood Glucose & & \\
A & 0.85 & $<0.01$ \\
B & 0.80 & $<0.01$ \\
D & 0.69 & $<0.05$ \\
\hline
\end{tabular}

Table I Linear correlations between doses of insulin $(0.025,0.05$, and $0.15 \mathrm{u} / \mathrm{kg} \mathrm{hr})$ and blood glucose changes ${ }^{1}$ Correlation coefficient derived from nine observations (three at each of the three doses of insulin) in each dog. 
produced significantly increasing degrees of hypoglycaemia.

\section{GASTRIC ACID RESPONSE}

The mean secretory responses to the insulin infusion in all tests are shown in figure 3. Low basal outputs of acid were constantly observed and no initial inhibition of acid secretion following the start of the infusion could be detected. In each test in each of the four dogs and with every dose of insulin tested, a delay in the onset of the acid response was observed. This delay varied between dogs for each dose, but was dose-related in that progressively shorter delays were noted with increasing doses of insulin, up to $0 \cdot 15 \mathrm{u} / \mathrm{kg} \mathrm{hr}$ (fig 3).

Following this initial delay in the onset of acid secretion, the acid output rapidly increased. With the lowest dose of insulin capable of initiating acid secretion $(0.025 \mathrm{u} / \mathrm{kg} \mathrm{hr}$ for dogs B and D and 0.05 $\mathrm{u} / \mathrm{kg} \mathrm{hr}$ for dogs $\mathrm{A}$ and $\mathrm{C}$ ), the output of acid tended to follow a plateau for the duration of the test. With the higher doses, a peak was reached after which the acid output declined in a stepwise fashion for the remainder of the infusion (fig 3). This decline in acid output, following the initial peak, resulted from a fall in both the volume and the acid concentration. of gastric juice. The PAO and the TAO increased significantly $(P<0.05$ or less, Student's $t$ test for unpaired data) with increasing doses of insulin up to $0.15 \mathrm{u} / \mathrm{kg} \mathrm{hr}$ (figs 4 and 5). Doubling the dose of insulin to $\mathbf{0 . 3 0} \mathrm{u} / \mathrm{kg} \mathrm{hr}$ tended to produce lower PAO and lower TAO, but this was not consistent and did not achieve statistical significance.

\section{CORRELATION BETWEEN BLOOD GLUCOSE} CHANGES AND OUTPUTS OF ACID

In two dogs (A and $C$ ) no secretion was initiated with a dose of insulin of $0.025 \mathrm{u} / \mathrm{kg} \mathrm{hr}$ (fig 3), which produced the lowest blood glucose values ranging from 44 to $60 \mathrm{mg} / 100 \mathrm{ml}$. In dog C a PBG of 40 $\mathrm{mg} / 100 \mathrm{ml}$ in one test resulted in significant acid production.

A statistically significant inverse linear correlation was observed between both the PAO and the TAO and the PBG and the LBG, indicating that the outputs of acid increased with increasing degrees of

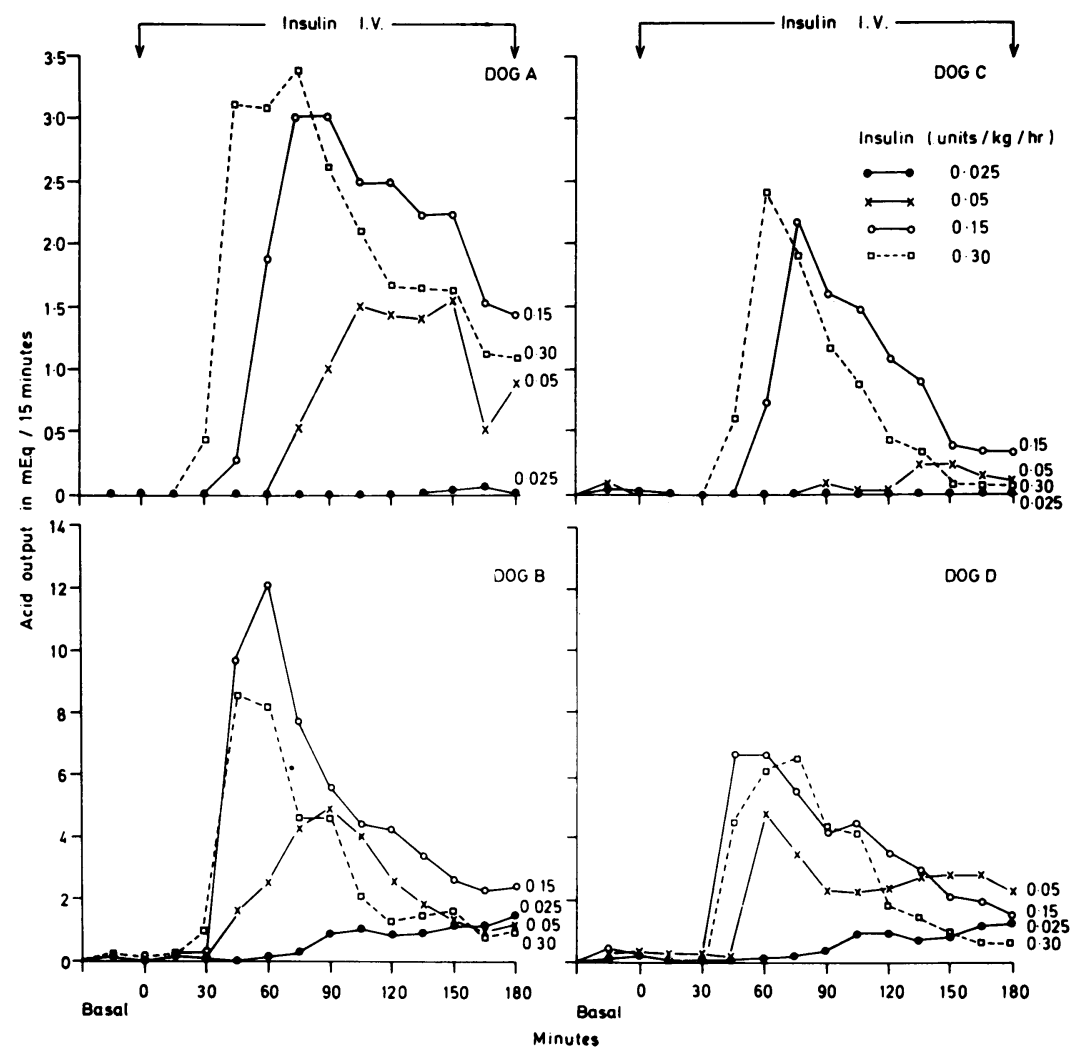

Fig 3 Output of acid to continuous insulin infusion. Each point represents the mean of three observations. 


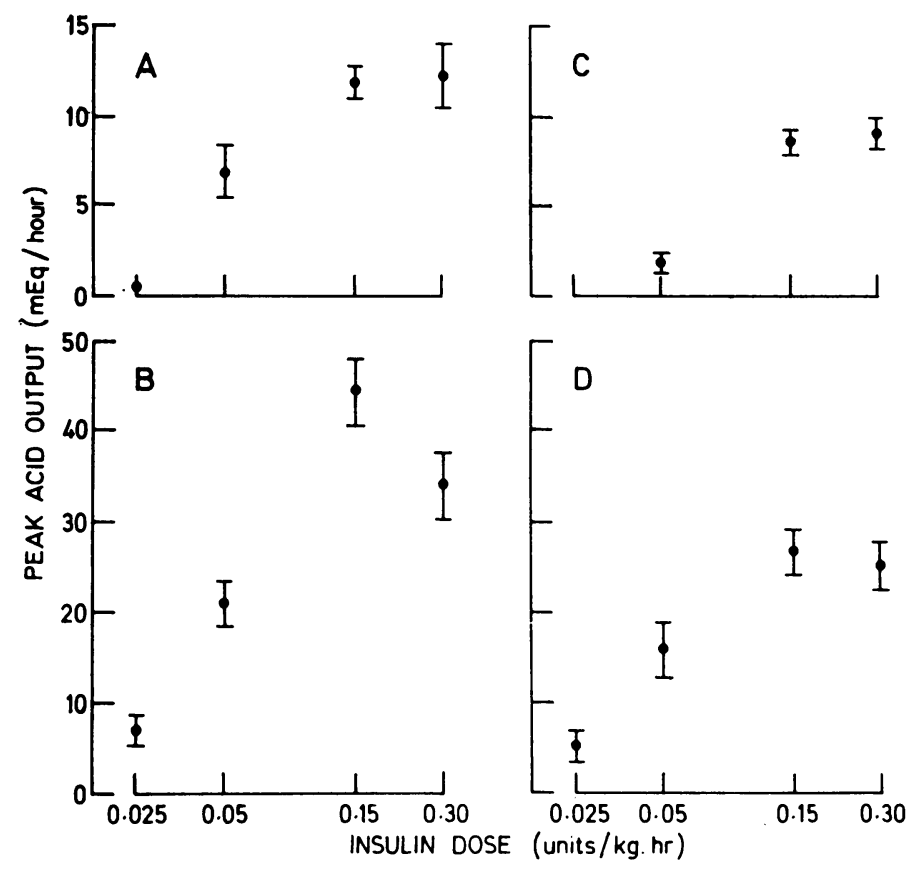

Fig 4 Peak acid output related to insulin dose. The PAO increased significantly $(p<0.05$ or less, Student's t test for unpaired data) with increasing doses of insulin up to $0 \cdot 15$ $\mathrm{u} / \mathrm{kg} \mathrm{hr}$. Each point represents the mean of 12 observations in four dogs $( \pm S E)$. Same applies to figure 5.

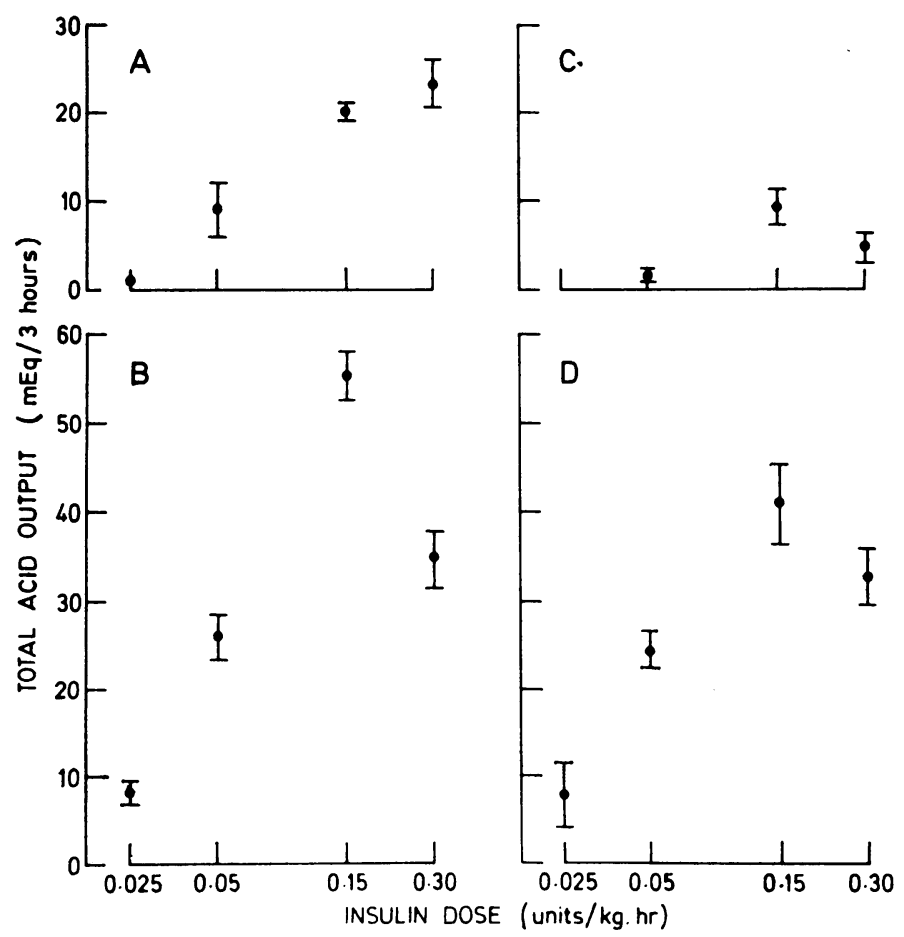

Fig 5 Total acid output related to insulin dose. The TAO increased significantly $(p<0.05$ or less, Student's $t$ test for unpaired data) with increasing doses of insulin up to $0 \cdot 15 \mathrm{u} / \mathrm{kg} \mathrm{hr}$. 


\begin{tabular}{|c|c|c|c|c|c|c|c|}
\hline \multirow[t]{3}{*}{ Dog } & \multirow[t]{3}{*}{ Acid Output } & \multicolumn{6}{|c|}{ Blood Glucose } \\
\hline & & \multicolumn{2}{|c|}{$P B G^{1}(m g / 100 m l)$} & \multicolumn{2}{|c|}{$L B G^{1}(m g / 100 m l)$} & \multicolumn{2}{|c|}{$\triangle B G^{1}(\%)$} \\
\hline & & $r$ & $p$ & $r$ & $p$ & $r$ & $p$ \\
\hline A & $\begin{array}{l}\text { PAO }^{2} \\
\text { TAO }\end{array}$ & $\begin{array}{l}-0.85 \\
-0.82\end{array}$ & $\begin{array}{l}<0.001 \\
<0.01\end{array}$ & $\begin{array}{l}-0.84 \\
-0.80\end{array}$ & $\begin{array}{l}<0.01 \\
<0.01\end{array}$ & $\begin{array}{l}+0.92 \\
+0.91\end{array}$ & $\begin{array}{l}<0.001 \\
<0.001\end{array}$ \\
\hline B & $\begin{array}{l}\text { PAO } \\
\text { TAO }\end{array}$ & $\begin{array}{l}-0.71 \\
-0.73\end{array}$ & $\begin{array}{l}<0.05 \\
<0.05\end{array}$ & $\begin{array}{l}-0.64 \\
-0.63\end{array}$ & $\begin{array}{l}<0.05 \\
<0.05\end{array}$ & $\begin{array}{r}+0.74 \\
+0.69\end{array}$ & $\begin{array}{l}<0.05 \\
<0.05\end{array}$ \\
\hline $\mathbf{C}$ & $\begin{array}{l}\text { PAO } \\
\text { TAO }\end{array}$ & $\begin{array}{l}-0.65 \\
-0.60\end{array}$ & $\begin{array}{l}<0.05 \\
<0.05\end{array}$ & $\begin{array}{l}-0.70 \\
-0.67\end{array}$ & $\begin{array}{l}<0.05 \\
<0.05\end{array}$ & $\begin{array}{l}+0.70 \\
+0.55\end{array}$ & $\begin{array}{l}<0.05 \\
>0.05\end{array}$ \\
\hline D & $\begin{array}{l}\text { PAO } \\
\text { TAO }\end{array}$ & $\begin{array}{l}-0.77 \\
-0.76\end{array}$ & $\begin{array}{l}<0.01 \\
<0.01\end{array}$ & $\begin{array}{l}-0.76 \\
-0.81\end{array}$ & $\begin{array}{l}<0.05 \\
<0.01\end{array}$ & $\begin{array}{r}+0.77 \\
+0.72\end{array}$ & $\begin{array}{l}<0.05 \\
<0.05\end{array}$ \\
\hline
\end{tabular}

Table II Linear correlations between blood glucose changes and gastric acid response

${ }^{1}$ PBG: plateau blood glucose; LBG: lowest blood glucose; $\triangle$ BG: $\triangle$ blood glucose 'PAO: peak acid output; TAO: total acid output.

$P<0.05$ or less: statistically significant correlation.

(DOG A )

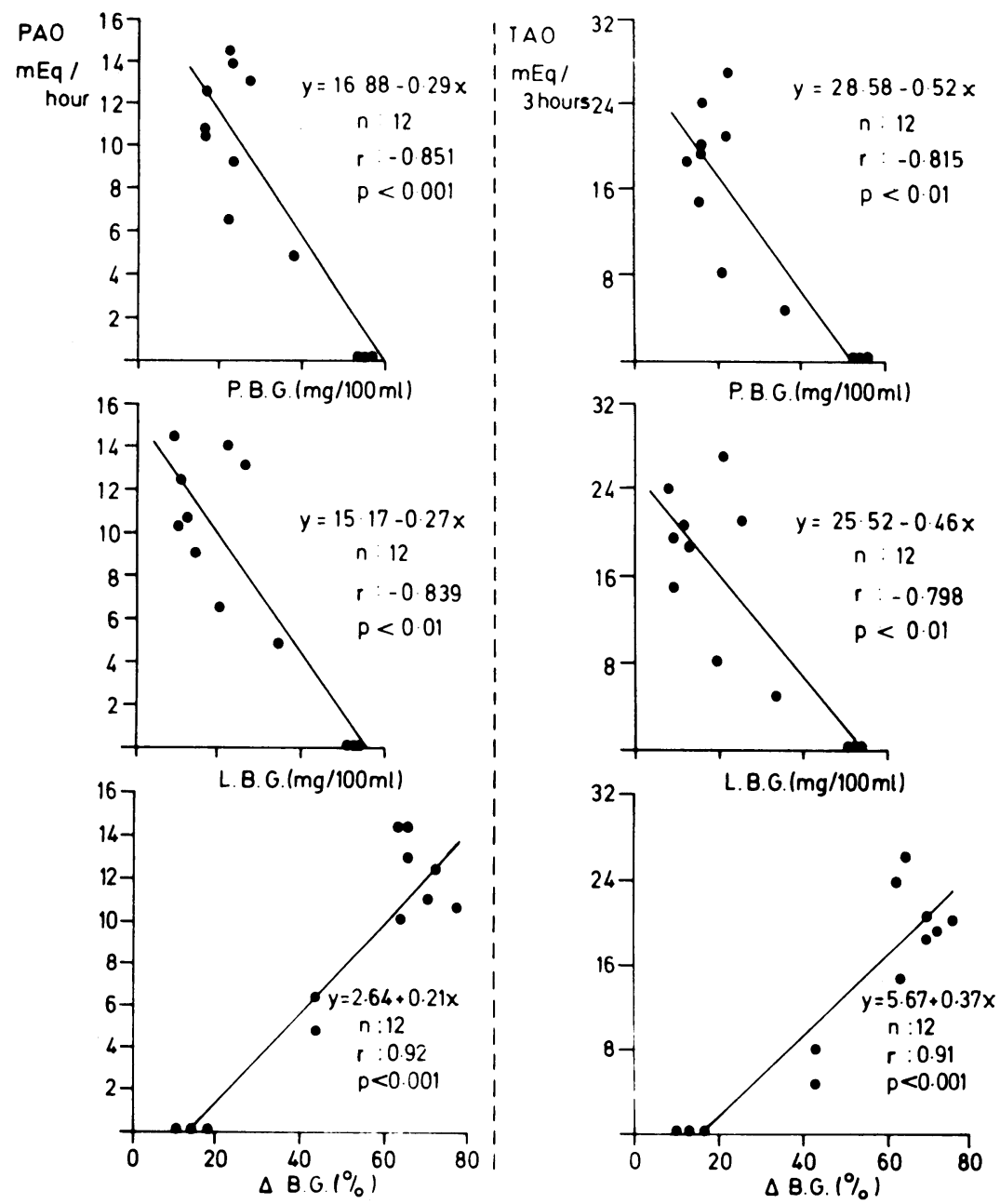

Fig 6 Linear correlations between acid changes and blood glucose. The peak acid output $(P A O)$ and the total acid output (TAO) both correlated significantly $(p<0.05$ or less) with the plateau blood glucose (PBG), the lowest blood glucose ( $L B G)$, and the $\triangle$ blood glucose $(\triangle$ $B G)$ in $\operatorname{dog} A$ (represented above) and in the other dogs (see table II). 
hypoglycaemia (table II, fig 6). The $\Delta$ BG also correlated significantly with the PAO in all dogs and with the TAO in all but one of the animals (table II).

\section{Discussion}

Our results indicate that insulin provides a quantitative glycopenic stimulus producing a quantitative vagal acid response, thus refuting the 'all-or-none' hypothesis.

In contrast to the single intravenous injection which produces a nadir of hypoglycaemia with a gradual return to normoglycaemic levels, the insulin infusion results in a prolonged 'plateau' of hypoglycaemia. The concept of an insulin infusion is not entirely new (Demand, Gross, and Berg, 1968; Carter et al, 1972) and we have observed a similar pattern of blood glucose response in healthy human subjects (Carter et al, 1972). Larger doses of insulin administered as a single injection will also tend to prolong the period of hypoglycaemia (Spencer and Grossman, 1971). In our experiments, graded doses of insulin up to $0.15 \mathrm{u} / \mathrm{kg} \mathrm{hr}$ produced graded levels of hypoglycaemia.

Similarly, graded doses of insulin resulted in a graded acid response. Such findings have been reported in man (Baron, 1970; Isenberg, Stening, Ward, and Grossman, 1969), in the dog (Cooke, 1969; Spencer and Grossman, 1971), and in the cat (Stening and Isenberg, 1969), where insulin was administered as a single intravenous injection.

The infusion of insulin produced a steady level of hypoglycaemia, but a peak rather than a plateau of acid secretion was observed with larger doses of insulin. Such findings would indicate that the acid response, initiated by the fall in blood glucose or the nadir, is not sustained by prolongation of the period of hypoglycaemia and that this phenomenon could be dose-dependent. Persistent hypoglycaemia would appear to provide a continuous glycopenic stimulus since lower doses of insulin tended to produce a steady state of acid secretion. However, prolonged hypoglycaemia due to larger doses of insulin may be concomitantly associated with important and persistent inhibition of acid secretion. This is suggested by the observation that the largest two doses of insulin used in our experiments produced peak acid outputs of comparable magnitude while the subsequent decline in acid secretion was consistently steeper and more important with the largest dose. Work is in progress to determine if changes in potassium levels are responsible for this phenomenon. In man, blood glucose values of less than $15 \mathrm{mg} / 100 \mathrm{ml}$ were associated with inhibition of gastric acid secretion (Baron, 1970). In the dog, blood 'sugar' values of less than $25 \mathrm{mg} / 100 \mathrm{ml}$ have been reported to be associated with inhibition of gastric acid secretion (Necheles, Olson, and Scruggs, 1942) and of pancreatic (Scott, Collignon, Bugel, and Johnson, 1941) and intestinal secretion (Kneller and Nasset, 1949). There was, however, a definite quantitative relationship between the insulin dose, the degree of hypoglycaemia, and the magnitude of the acid response.

No initial inhibitory phase of acid secretion could be detected following the start of the insulin infusion. This is contrary to previous workers' findings (Olson and Necheles, 1955) who used insulin preparations 'contaminated' with glucagon, which might have been responsible for such an effect (Aylett, 1962), but is in agreement with Spencer and Grossman's findings (1971) who used, like us, purified insulin. Insulin is by itself, however, a powerful inhibitor of histamine-(Hirschowitz and Robbins, 1966) and pentagastrin-(Hirschowitz and Sachs, 1972) induced acid secretion. In our tests, a delay in the onset of the acid response was consistently seen following the commencement of the infusion. Such delay appeared to be dose-related in that shorter delays were observed with larger doses of insulin.

We are grateful to Professor A. P. M. Forrest for his constant encouragement and to Dr M. I. Grossman and Dr C. F. Code for their helpful advice. We are also indebted to Dr I. W. Percy-Robb for his help with the glucose estimations, to Mrs Margaret Coyle for her technical assistance, and to Miss Judy Pfeifer for the preparation of the manuscript.

R. R. Dozois was in receipt of the R. S. McLaughlin fellowship (Canada).

References

Aylett, P. (1962). The effects of glucagon and glucagon-free insulin upon gastric secretion in peptic ulcer patients. Clin. Sci., 22. 179.184.

Baron, J. H. (1963). Studies of basal and peak acid output with an augmented histamine test. Gut, 4, 136-144.

Baron, J. H. (1970). Dose response relationships of insulin hypoglycaemia and gastric acid in man. Gut, 11, 826-836.

Carter, D. C., Dozois, R. R., and Kirkpatrick, J. R. (1972). Insulin infusion test of gastric acid secretion. Brit. med. J., 2, 202-204.

Cooke, A. R. (1969). Acid and pepsin secretion in response to endogenous and exogenous cholinergic stimulation and pentapeptide. Aust. J. exp. Biol. med. Sci., 47, 197-202.

Davis, R. A., Brooks, F. P., and Robert, C. M., Jr. (1965). Gastric secretory response to graded insulin hypoglycaemia. Amer. J. Physiol., 208, 6-8.

Demand, H. A., Gross, H. U., and Berg, G. (1968). Effects of continuous insulin infusions on unstimulated human gastric secretion. Gastroenterology, 54, 1038-1049.

Hirschowitz, B. I. and Robbins, R. C. (1966). Direct inhibition of gastric electrolyte secretion by insulin, independent of hypoglycemia or the vagus. Amer. J. dig. Dis., 11, 199-212.

Hirschowitz, B. I., and Sachs, G. (1972). K Cl reversal of insulin inhibition and fade in pentagastrin-stimulated gastric secretion. Amer. J. Physiol., 223, 305-309.

Hollander, F., Jemerin, E. E., and Weinstein, V. A. (1942). An insulin test for differentiating vagal from non vagal stomach pouches. (Abstr.) Fed. Proc., 1, 116. 
Isenberg, J. I., Stening, G. F., Ward, S., and Grossman, M. I. (1969). Relation of gastric secretory response in man to dose of insulin. Gastroenterology, 57, 395-398.

Jögi, P., Ström, G., and Uvnäs, B. (1949). The origin in the CNS of gastric secretory impulses induced by hypoglycemia. Acta physiol. scand., 17, 212-221.

Kneller, A. W., and Nasset, E. S. (1949). Relationship of insulin hypoglycemia to intestinal secretion. Amer. J. Physiol., 159, 89-94.

Necheles, H., Olson, W. H., and Scruggs, W. (1942). The effect of insulin on gastric secretion. (Abstr.) Fed. Proc., 1, 62.

Olson, W. H., and Necheles, H. (1955). Primary depression of gastric secretion by insulin in normal man. J. Amer. med. Ass., 159 1013-1014.

Scott, V. B., Collignon, U. J., Bugel, H. J., and Johnson, G. C. (1941). The relation of external pancreatic secretion to variations in blood sugar. Amer. J. Physiol., 134, 208-218.

Spencer, J., and Grossman, M. I. (1971). The gastric secretory response to insulin: an 'all-or-none' phenomenon? Gut, 12, 891-896.

Stening, G. F., and Isenberg, J. I. (1969). Insulin-induced acid secretion after partial vagotomy in dogs and cats. Amer.J. Physiol., 217, 962-964.

Thomas, J. E. (1941). An improved cannula for gastric and intestinal fistulas. Proc. Soc. exp. Biol. (N.Y.), 46, 260-261.

\section{The May 1973 Issue}

\section{THE MAY 1973 ISSUE CONTAINS THE FOLLOWING PAPERS}

Value of small intestinal bile acid analysis in the diagnosis of the stagnant loop syndrome T. C. NORTHFIELD, B. S. DRASAR, AND J. T. WRIGHT

Bile acids in the diarrhoea of ileal resection W. D. MITCHELL, J. M. FINDLAY, R. J. PRESCOTT, M. A. EASTWOOD, AND D. B. HORN

Skeletal muscle blood flow and neurovascular reactivity in liver disease MICHAEL LUNZER, $S$. P. NEWMAN, AND SHEILA SHERLOCK

Serum autoantibodies and immunoglobulins in hepatitis-associated antigen (HAA)-positive and -negative liver disease F. J. DUDLEY, M. J. O'SHEA, A. AJDUKIEWICZ, AND S. SHERLOCK

Liver disease and cell-mediated immunity in hepatitis-associated antigen (HAA) carriers T. D. BOLIN, A. E. DAVIS, AND A. G. LIDDELOW

Gel filtration studies on immunoreactive gastrin in serum from Zollinger-Ellison patients JENS F. REHFELD AND FLEMMING STADIL

Discordance for childhood coeliac disease in monozygotic twins J. A. WALKER-SMITH

Leucocyte migration studies with spleen preparations in Crohn's disease ELIZABETH R. RICHENS, K. R. GOUGH, AND M. J. WILLIAMS
Action of oral metoclopramide on the gastrooesophageal junction in man J. B. DILAWARI AND J. J. MISIEWICZ

An evaluation of ${ }^{75} \mathrm{Se}$ Selenomethionine scanning as a test of pancreatic function compared with the secretin-pancreozymin test JOAN BRAGANZA, MAIR CRITCHLEY, H. T. HOWAT, H. J. TESTA, AND H. B. TORRANCE

Rectal hyperpolarization following intestinal bypass for obesity J. RASK-MADSEN, P. BRIX JENSEN, AND J. O. LUND

Pharmacological characteristics of the non-striated anorectal musculature in cats F. PENNINCKX, R. KERREMANS, AND J. BECKERS

\section{Technique}

A miniature digital millivoltmeter for measuring intestinal transmural electric potential difference D. L. WINGATE

\section{Progress report}

Prostaglandins and the gastrointestinal tract SHEILA L. WALLER

The British Society of Gastroenterology spring meeting

Notes and activities

Copies are still available and may be obtained from the PUBLISHING MANAGER, BRITISH MEDICAL ASSOCIATION, TAVISTOCK SQUARE, LONDON, WC1H 9JR, price $87 \frac{1}{2} \mathrm{p}$ 